\title{
ELECTRONIC EAVESDROPPING: A NEW APPROACH
}

THE PROBLEM DELIMITED

Justice Brandeis, dissenting in Olmstead v. United States, ${ }^{1}$ expressed a sentiment which no doubt has been felt by many who have sensed the encroachment of government officers into their lives:

The Makers of our Constitution ... sought to protect Americans in their belicfs, their thoughts, their emotions and their sensations. They conferred, as against the Government, the right to be let alone-the most comprchensive of rights and the right most valued by civilized men. ${ }^{2}$

The right of privacy, in the words of Lord Nathan, is the privilege to "shut one's door upon the world and to do or to say what one will ... secure in the knowledge that one is alone."3

The electronic devices now available to the eavesdropper are frightening in light of the meager restrictions on their use. Parabolic microphones are now available which, under ideal conditions, can pick up a conversation at a distance of 500-1000 feet. ${ }^{4}$ Microwave beam devices, now well on the way toward being perfected, will be able to penetrate virtually any structure and return every word spoken within. ${ }^{5}$ Potential development places no restriction on one's imagination. ${ }^{6}$

This development of privacy probing electronic devices has, on the one hand given law enforcement officers a valuable weapon for the detection and prevention of crime, but on the other hand has had the effect of eroding a good portion of the individual's interest in privacy. This Comment will explore current constitutional and statutory safeguards and will assess whether, under present constitutional interpretations and implications, the "right to privacy" 7 can be sufficiently protected.

The constitutional history of electronic eavesdropping begins in 1928 with the landmark case of Olmstead v. United States. ${ }^{8}$ In a 5-4 decision the Supreme Court held that federal agents who had tapped defendant's telephone wires without a trespass had not violated the fourth or fifth amendments. ${ }^{0}$ Writing for the majority, Chief Justice Taft sharply limited the scope of the fourth amendment

\footnotetext{
1277 U.S. 438,471 (1928).

2 Id. at 478 (dissenting opinion).

3 Nathan, Eavesdropping, 225 L.T. 119, 120 (1958).

* See Dash, Schwartz \& Knowlton, The Eavesdroppers 350 (1959) [Hercinafter cited as DASH].

5 See $I d$. at $357-58$.

$6 \mathrm{~A}$ recorder no larger than an eraser, capable of running for months on atomic batterics, is among the suggestions. Lipset, The Wiretapping-Eavesdropping Problem: A Private Investigator's View, 44 MINN. L. REv. 873, 888 (1960). A miniature television transmitter may now be available which could be used to tune in on a suspect's entire home. Hearings before the Subcommittee on Constitutional Rights of the Senate Committee on the Judiciary, 87 Cong., 1st Sess. 421 (1961).

7 The term, "right of privacy," has been used in a number of senses to express what are, in fact, a variety of rights. See Beancy, The Constitutional Right to Privacy in the Supreme Court, 1962 SuP. Cr. REv. 212.

8277 U.S. 438 (1928). For a thorough discussion of that case see Beaney, supra note 7 , at $9,218-28$.
} 
by insisting that in order for there to be a violation the wiretapper must commit a trespass: "The Amendment does not forbid what was done here. There was no searching. There was no seizure. The evidence was secured by the use of the sense of hearing and that only. There was no entry of the houses or offices of the defendants."11

Federal control of wiretapping was thereby left to the legislature. Seven years later Congress passed the Federal Communications Act of 1934 with the basic section 605 providing in part: " $[\mathrm{N}]$ o person not being authorized by the sender shall intercept any communication and divulge or publish the existence, contents, substance, purport, effect, or meaning of such intercepted communication to any person ...." 12 As a result of this enactment, the Olmstead decision is no longer important in the area of wiretapping. However, the Supreme Court in Goldman v. United States, ${ }^{13}$ found non-telephonic electronic eavesdropping to be indistinguishable in principle from wiretapping, and therefore the doctrine of Olmstead has enjoyed continued vitality. Those concerned with the problems presented by wiretapping and section 605 are referred to a sample of the plethora of articles on this subject. ${ }^{14}$ The remainder of this Comment will focus solely on electronic eavesdropping other than wiretapping.

Whether the Court took the desirable turn in Olmstead and, more immediately, whether its course should have been halted somewhere along the line ${ }^{15}$ has received no small amount of comment. Most writers ${ }^{16}$ have taken the position that the route followed by the Court has led it steadily away from the true spirit of the fourth amendment.

0 The defendant had also urged that the fifth amendment had been violated. The Court answered this contention: "[T]here is no room in the present case for applying the Fifth Amendment unless the Fourth Amendment was first violated." 277 U.S. at 462 . For the development of this relationship see Entick v. Carrington, 19 How. St. Tr., col. 1029 (Ct. C. P. 1765) ; Boyd v. United States, 116 U.S. 616 (1886); Gouled v. United States, 255 U.S. 298 (1921).

10 Earlier cases had in dicta recognized a right of privacy protected by the fourth amendment that was not hased on a biteral reading of the amendinent-i.e., a recognition that the amendment protected searches that were not physical. See, e.g., Weeks v. United States, 232 U.S. 383 (1914) ; Boyd v. United States, supra note 9; cf. Entick v. Carrington, supra note 9. Justice Brennan, dissenting in Lopez v. United States, 373 U.S. 427, 453-60 (1963), scans this whole area and advocates a more flexible interpretation of the fourth amendinent such as recognized by earlier cases. See also BeISEx, Control Over IItEgal ENForcement of the Crminnat Law: Role of twe Supreare Court 21 (1955); Beaney, supra note 7, at 215-18.

11 Olmstead v. Umited States, 277 U.S. 438, 464 (1928).

1248 Stat. 1103 (1934), 47 U.S.C. $\$ 605$ (1962).

13316 U.S. 129 (1942).

14 The classic commentary is Westin, The Wire-Tapping Problem: An Analysis and a Legislative Proposal, 52 Coudm. L. Rev. 165 (1952). See also Kamisar, The WiretappingEavesdropping Problem: A Professor's View, 44 MINn. L. REv. 891 (1960); Rogers, The Case for Wiretapping, 63 YaLe L.J. 792 (1954); Rosenzweig, The Lave of Wire Tapping, 32 CoRnert L.Q. 514 (1947); Schwartz, On Current Proposals to Legalize Wire Tapping, 103 U. PA. L. Rev. 157 (1957); Note, 111 U. PA. L. REv. 832 (1963).

15 Specifically, this would have been at either Goldman v. United States, 316 U.S. 129 (1942); or On Lee v. United States, 343 U.S. 474 (1952); or Lopez v. United States, 373 U.S. 427 (1963).

16 Perhaps the nuost violent commentary is by Justice Brennan, dissenting in Lopez v. United States, 373 U.S. 427, 466 (1963). For a summary of the views of the Suprene Court justices see King, Wire Tapping and Electronic Surveillance: A Neglected Constitutional Con- 
II

\section{CURRENT LEGAL RESTRICTIONS ON EAVESDROPPING}

\section{A. The Progeny of Olmstead}

Section 605 was not meant to apply to non-telephonic electronic eavesdropping, ${ }^{17}$ and there is no other federal statute in this field. Federal law is in no way violated by non-telephonic eavesdropping unless it results in an "unreasonable search and seizure" in violation of the fourth amendment. ${ }^{18}$ The Supreme Court, in a hine of cases following Olmistead, has given little consideration to reasonableness but rather has concentrated on the requirement of an actual invasion of the defendant's property.

Goldman v. United States ${ }^{18}$ was the first case to apply the reasoning of Olmstead. Federal agents entered defendant's office without authorization and installed a recording device. This apparatus did not function properly but the agents were able to hear everything they needed by placing another device, a detectaphone, against the outer wall of defendant's room. Following the reasoning of Olmstead, ${ }^{20}$ the Supreme Court affirmed admittance of the evidence, holding that the initial trespass in entering the office had in no way tainted the evidence obtained "with the detectaphone which had not required a trespass. Goldman

sideration, 66 Dick. L. Rev. 17, 21-24 (1961). For similar views of other writcrs sec, e.g., BEISEx, op. cit. supra note 10, at 33; Kamisar, supra note 14, at 925 ; King, stupra at 21-24; Williams, The Wiretapping-Eavesdropping Problem: Defense Counsel's View, 44 MnNo. L. REv. 855, 862 (1960). See also DASE 383-441; Westin, Wiretapping: The Quiet Revolution, 29 COMOMENTARY 333 (1960); cf. Hearings Before the Subcontmittee on Constitutional Rights of the Sente Committee on the Juticiary, 85 Cong., 2d Sess. 1457-62 (1958) [hercinafter cited as 1958 Hearings]. Some writers, however, have not vicwed the Court's position so critically. See, e.g., Parker, Surveillance by Wiretapping or Dictograph: Threat or Protection?, 42 CaIIF. L. Rev. 727 (1954); Rogers, The Case for Wire Tapping, 63 Yale L.J. 792 (1954); Silver, The Wiretapping-Eavesdropping Problem: A Prosecutor's View, 44 MnN. L. Rev. 835 (1960).

17 Goldman v. Umited States, 316 U.S. 129, 133-34 (1942). Sce also DAsa 427.

18 U.S. ConsT. amend. IV provides: "The right of the people to be secure in their persons, houses, papers, and effects, against unrcasonable searches and seizures, shall not be violated, and no Warrants shall issue, but upon probable cause, supported by Oath or affirmation, and particularly describing the place to be searched, and the person or things to be seized."

18316 U.S. 128 (1942).

20 Actually, the Olmstead reasoning has been discarded in part. The rationale for the holding in Olmstead can be divided into three reasons submitted by the Court: (1) there was not an illegal seizure because no "tangible property" of the defendant had been seized, (2) the defendant intended his voice to leave the room and it therefore was not protected outside of his house, and (3) there was no illegal scarch because there was not a "physical trespass." 277 U.S. 438, 464, 466 (1928). Grounds (1) and (2) have been abandoned. It is now well established that the evidence which is seized need not be tangible. Silverman v. United States, 365 U.S. 505 (1961). In Goldman v. United States, 316 U.S. 129, 135 (1942), the Court found no merit in defendant's contention that there had been a violation of the fourth amendment because he had not intended his voice to leave the room. Thus, the basis on which Olmstead was decided has been shaved to the absence of a "physical trespass" alone. See Lopez v. United States, 373 U.S. 427, 460-61 (1963) (Brennan, J., dissenting); DASE 386-87; King, supra note 16 , at $21-24$.

Apparently the Court in Olmstead meant to define "physical trespass" as an "actual physical mvasion of his [defendant's] house or curtilage . ..." 277 U.S. at 466. 
strongly suggested that evidence obtained by a trespass of either the installer or the device itself ${ }^{21}$ would violate the fourth amendment. ${ }^{22}$

Goldman was followed by On Lee v. United States ${ }^{23}$ which involved the use of a recording device but in a very different sense. In On Lee an old acquaintance visited defendant's laundry and engaged him in conversation. Defendant made some damaging statements concerning narcotics violations. Unknown to him, his old acquaintance was an agent of the United States Bureau of Narcotics equipped with a device transmitting those admissions to a government official outside. The official was allowed to testify. ${ }^{24}$ The Court by a 5-4 vote held that the defendant's rights under the fourth amendment had not been violated because a trespass had not been committed. ${ }^{25}$ The Court emphasized that "Chin Poy entered a place of business with the consent, if not by implied invitation of the petitioner."26 Another face-to-face recording was held admissible in the recent case of Lopez $v$. United States ${ }^{27}$ in which a treasury agent equipped with a miniature recorder taped an attempt by the defendant to bribe him. The implications of Lopez are by no means clear, but on its face it appears to be cut from the same pattern as On Lee.

The case of Silverman $v$. United States ${ }^{28}$ was the first to directly decide when the fourth amendment is violated by electronic eavesdropping. District of Columbia police had pushed a "spike mike" through the party wall of an adjoming house until it touched the heating duct in the house occupied by the petitioner, "thus converting their entire heating system into a conductor of sound." 20 The court of appeals affirmed ${ }^{30}$ the conviction based on evidence from the spike microphone. Testimony indicated that microplione could not have penetrated more than $5 / 16$ of an inch into the petitioner's home and the court of appeals could not believe "that the respective riglits are to be measured in fractions of inches." 31 The Supreme Court unanimously reversed stating that the "decision here does not turn upon the technicality of a trespass upon a party wall as a

21 "[I]f the apparatus had been used it might, with reason, be claimed that the continuing trespass was the concomitant of its use." 316 U.S. 129, 134-35 (1942).

22 See Irvine v. California, 347 U.S. 128 (1954), which indicated that the fourth amendment is violated if the eavesdropper trespasses in securing his evidence. Police officers had entered defendant's house with a key they had made and installed a microphone. A second entry was necessary to relocate the device. Although the evidence was held admissible in a state court (on the basis of a line of cases which have subsequently been overruled), it is clear that the planting of the device constituted an unreasonable search: "Each of these repeated entries of petitioner's home without a search warrant or other process was a trespass .... Few pohce measures have come to our attention that more flagrantly, dehiberately, and persistently violated the fundamental principle declared by the Fourth Amendment ...." Id. at 132 .

23343 U.S. 747 (1952).

24 The government informer, Chin Poy, however, did not appear at trial. This no doubt was due to the fact that Chin Poy was close enough to the underworld to be of future value and, for this same reason, to be of low credibility as a witness. Id. at 749-50.

$251 d$. at 751 .

$26 I d$. at $751-52$.

27373 U.S. 427 (1963).

28365 U.S. 505 (1961).

20 Id. at 507.

30 United States v. Silverman, 275 F.2d 173 (D.C. Cir. 1960), affrming 166 F. Supp. 838 (D.D.C. 1958). For a discussion of the case at the court of appeals level see Kamisar, supra note 14 , at $925-29$.

$\mathbf{3 1}$ United States v. Silverinan, supra note 30 , at 178. 
matter of local law. It is based upon the reality of an actual intrusion into a constitutionally protected area." 32

The Court in Olmstead and Goldman had refused to invoke the fourth amendment without a physical trespass. In Silverman the Court, while disclaiming a reliance on the law of trespass, did no more than refine a physical trespass into a "actual intrusion into a constitutionally protected area." 33 The effect of this new language has been minimal; ${ }^{34}$ the fourth amendment is still not violated in the absence of a physical invasion. Apparently this new requirement does no more than free the Court, on occasions such as Silverman, from considering overly technical rules of trespass. ${ }^{35}$

\section{B. Physical Invasion in General-Protection from Eye and Ear}

The Supreme Court has always been intent upon protecting persons from unauthorized physical intrusions onto "their persons, homes, and property . . . ." 30 If the invasion is wrongful, all evidence obtamed as a result of that invasion whether physical, verbal, or visual is excluded. ${ }^{37}$ The Silverman case exemplifies this traditional fourth ainendment protection from a physical invasion. Silverman dealt with an electronic hearing device but the same principle would be applicable to visual aids. Thus, both the auditory and the visual eavesdropper using a super-sensitive device are restricted in the same manner as an eavesdropper who must rely on his natural senses.

32365 U.S. 505, 512 (1961).

33 Ibid.

34 A circuit court opinion accurately summed up the effect as follows: "[The] courts of appeal which bave considered Silverman have found no vacillation in the guiding principle [i.e., the Olmstead doctrine]." Anspach v. United States, 305 F.2d 48, 51 (10th Cir.), cert. denied, 371 U.S. 826 (1962). Accord, Todisco v. Umited States, 298 F.2d 208 (9th Cir. 1961), cert. denied, 368 U.S. 989 (1962); United States v. Kabot, 295 F.2d 848 (2d Cir. 1961), cert. denied, 369 U.S. 803 (1962); Carnes v. United States, 295 F.2d 598 (5th Cir. 1961), cert. denied, 369 U.S. 861 (1962).

For an excellent discussion of Silverman and a more interesting interpretation, which has not been accepted, see Note, The Supreme Court, 1960 Term, 75 HARv. L. REv. 40, 185-87 (1961).

35 But cf. Lopez v. United States, 373 U.S. 427,461 n.10 (1963) (Brennan, J., dissenting). Justice Brennan argued that because Silverman did not require a technical trespass the earlicr cases of Olnistead, Goldman, and On Lee were now without support since they had required one.

36 U.S. Const. amend. IV.

37 Silverman v. United States, 365 U.S. 505, 512 (1961) (verbal). See Wong Sun v. United States, 371 U.S. 471, 485-86 (1963) (physical and verbal), noted 51 CALLF. L. REv. 637 (1963); McDonald v. United States, 355 U.S. 451 (1948) (visual); McGinnis v. United States, 227 F.2d 598, 603 (1955); People v. Cahan, 44 Cal. 2d 434, 282 P.2d 905 (1955) (verbal).

In MCDonald, supra, police officers gained access to the house by opening the window leading into the landlady's premises. They proceeded to the common ballway where one of them observed through a transom the defendant carrying on an illegal lottery. The fourth amendment was held violated. Justice Jackson, in a separate concurring opinion, explained the reason for the violation as follows: Every tenant has a constitutionally protected interest in the security of the entire building, and as the police officers had not obtained access legally, they were invading the defendant's protected area. They could not thereby profit by their wrong; the evidence was inadmissible. 335 U.S. at 458-59 (concurring opinion). Compare the reasoning of Justice Jackson with that in Bielicki v. Superior Court, $57 \mathrm{Cal}$. 2d 602, 371 P.2d 288, 21 Cal. Rptr. 552 (1962).

For a discussion of this general area see Kamisar, Illegal Searches or Seizures and Contemporaneous Incriminating Statements: $A$ Dialogue on a Neglected Area of Criminal Procedure, 1961 U. Inc. L.F. 78, 123-28. See also Nueslein v. District of Columbia, 115 F.2d 690 (D.C. Cir. 1940), which is discussed by Kamisar as is McDonald. 
While several Supreme Court justices ${ }^{38}$ and many legal writers ${ }^{39}$ have rejected the Court's position as to electronic hearing devices, the use of visual aids to invade privacy has not aroused any appreciable concern. ${ }^{40}$ The use of binoculars ${ }^{41}$ has not been questioned nor has the use of a searchlight ${ }^{42}$ at night. Cameras are now capable of capturing images both in the dark ${ }^{43}$ and beyond the range of the vision of the human eye, ${ }^{44}$ yet pictures taken with such equipment are routinely admitted into evidence. If the value of a picture at trial is accuracy, cannot the same be said for the recording of the minifon? It would also seem that binoculars could invade one's privacy in a somewhat analogous fashion to a spike niicrophone or a parabolic microphone, both of which reach farther than the ear, much as binoculars stretch eyesight. Yet it is probably fair to say there is a greater potential invasion of privacy by the electronic listening devices due to the greater security which seems to be afforded by enclosed places. When - and this may be in the not-too-distant future-walls cease to be a barrier to visual aids, it will be the visual eavesdropper who poses the greatest threat to the right of privacy.

The course of the physical invasion theory of restriction has generally followed the law of trespass but, as seen in Silverman, the Court has not felt compelled to observe certain technical rules of this ancient law. ${ }^{45}$ The exceptions,

38 See, e.g., Lopez v. United States, 373 U.S. 427, 446 (1963) (Brennan, J., dissenting; Justices Douglas and Goldberg joined in the dissent). King, supra note 16, at 21-24, explains the positions of all earlier objecting justices.

${ }^{39}$ See, e.g., secondary authorities cited at note 16 supra.

40 The only real concern arises in a most peculiar situation. In York v. Story, 324 F.2d 450 (9th Cir. 1963), a civil prosecution against police officers under REv. STAT. $\$ 1979$ (1875), 42 U.S.C. \$ 1983 (1958), required a showing that a constitutional right had been violated. The plaintiff had complained at the police station of being assaulted and was asked to have her picture taken to record any bruises. She insisted that no bruises were visible but was directed to undress and was photographed in the nude in indecent positions. A policewoman was present at the station but was not suminoned. The pictures were distributed to other police officers and subsequently reprints were inade. With regard to a violation of the fourth amendment the court said: "The alleged act [photographing] ... may or may not constitute an unreasonable search in the Fourth Amendinent sense. But if we should hold that it does, this would not dispose of the whole case for the alleged subsequent acts . . . in distributing the prints . . could hardly be characterized as unreasonable searches." Id. at 454. The court, however, reversed the lower court's dismissal of the complaint (for failure to state a claim upon which relief could be granted) on the basis that the fourteenth annendment's right of privacy extends to the photographing of one's nude body in such an unreasonable manner. Id. at 456 .

41 Hodges v. United States, 243 F.2d 281 (5th Cir. 1957). In On Lee v. United States, 343 U.S. 747,754 (1952), the Court compared the use of a hidden transmitter to visual aids: "The use of bifocals, field glasses or the telescope to magnify the object of a witness' vision is not forbidden search and seizure, even if they focus without his knowledge or consent upon what one supposes to be private indiscretions."

42 United States v. Lee, 274 U.S. 559, 563 (1927). In Lee the Court said that the use of a searchlight was "coinparable to the use of a marine glass or a field glass" and "not prohibited by the Constitution." Ibid. See also Haerr v. United States, 240 F.2d 533 (5th Cir. 1957) (shining a flashlight into a car not a search). The notion that viewing soinething which is visible is not a "search" has had few dissenters. Justice Brennan is one. See Lopez v. United States, 373 U.S. 427, 459 (1963) (Brennan, J., dissenting). Compare Bielicki v. Superior Court, 57 Cal. 2d 602, 371 P.2d 288, 21 Cal. Rptr. 552 (1962) with People v. Regalado, 193 Cal. App. 2d 437, 14 Cal. Rptr. 217 (1961).

43 See Dasz 373-74. In addition, triggering devices and remote control can be used to operate these caineras. Id. at 374-75.

44 Ibid.

45 In Jones v. United States, 362 U.S. 257 (1960), the Court said that "it is unnecessary and ill-advised to import into the law surrounding the Constitutional right to be free from 
however, are few and in nearly all cases the invasion becomes wrongful when a trespass is committed.

False representations of mission to gain entry, as found in On Lee and Lopez, are instances where tort law would possibly have ruled trespass by fraud or $a b$ initio. ${ }^{46}$ Generally speaking the courts have not found this sort of crime detection distasteful and in On Lee the Court threw out both of these technicalities. ${ }^{47}$ The defendant must consent to the entry but the consent may take the form of an implied invitation..$^{48}$ Obviously the entrant may use no force, ${ }^{40}$ and

unreasonable searches and seizures subtle distinctions, developed and refined by common law ...."Id. at 266. The Jones case presents the problem of who has "standing" to complaim of an unreasonable search and seizure. A possessory interest in the premises is not required; all that is needed to allow a defendant to complain of the unreasonable search (which would include a physical invasion) is that he be legitimately on the premises searched. Bul see Henzel v. United States, 296 F.2d 650 (5th Cir. 1961), for an attempt to cut back on the broad approach of Jones. Technical rules of trespass were also rejected in Chapman v. United States, 365 U.S. 610 (1961), and United States v. Jeffers, 342 U.S. 48 (1951).

Justice Brennan, dissenting in Lopez v. United States, 373 U.S. 427, 460-61 (1963), argued that because the Court had "refused to crowd the Fourth Amendment into the mold of local property law," it was an indication that the Olmstead holding which had required a physical trespass was no longer supported. Bul see the Olmstead definition of "physical trespass" at note 20 supra. It appears that Olmstead did not require a technical trespass, and if it did, Silverman has confined the holding as really requiring a physical invasion. Silverman v. United States, 365 U.S. 505, 509 (1961). Thus, the Court's refusal to follow local property law is in no way inconsistent with the vahidity of Olmslead.

46 See Prosser, Torts $\S \S 18,25$ (2d ed. 1955); SalMond, Torts $\$ \S 46,50$ (12th ed. 1957).

47 On Lee v. United States, 343 U.S. 747, 752 (1952). The Court rehed on McGuire v. United States, 273 U.S. 95, 98, 100 (1927), which had decided that trespass $a b$ initio belonged to civil law and not to the fourth amendment. The Court in $M c G u i r e$ was of the opinion that "a criminal prosecution is more than a game in which the government may be checkmated and the game lost merely because its officers have not played according to the rule." 273 U.S. at 99. Similarly, the Court in On Lee rejected a possible trespass by fraud relying on the rationale of $M$ cGuire, 343 U.S. at 752 . The rationale of On Lee in turn seems to be assumed by the Court in Lopez. 373 U.S. 427, 437-38 (1963).

48 See, e.g., id. at 438; On Lee v. United States, 343 U.S. 747, 751-52 (1952); Todisco v. United States, 298 F.2d 208 (9th Cir. 1961), cert. denied, 368 U.S. 989 (1962).

A number of California cases have dealt with this question and have also, although with less difficulty, concluded that there inust be an impled invitation. An imphed invitation here probably means no more than a willingness to receive. Sce, e.g., People v. Wootan, $195 \mathrm{Cal}$. App. 2d 481, 15 Cal. Rptr. 833 (1961); People v. Albert, 182 Cal. App. 2d 729, 9 Cal. Rptr. 473 (1960) ; People v. Goldberg, 152 Cal. App. 2d 562, 314 P.2d 151 (1957).

Even Justice Brennan does not object to the deception. United States v. Lopez, 373 U.S. 427, 465 (1963) (dissenting opinion). Justice Frankfurter in On Lee v. United States, supra, thought that this type of "fraud" "makes for lazy and not alert law enforcement." 343 U.S. at 761 (dissenting opinion).

It appears that the Supreme Court will not be so quick to find consent when the misrepresentation is in any way affirmative. See, e.g., Wong Sun v. United States, 371 U.S. 471, 482-83 (1963) (agent stated that he had come for his laundry); Gouled v. Umited States, 255 U.S. 298 (1921). In Gouled a government officer gained entry to defendant's business by pretending to make a friendly call and, in defendant's absence, took a paper which was used to convict him. The Court said that the fourth amendment prohibits admissions obtained by force and coercion and also by "stealth." Id. at 306 . The case, however, has been distinguished as resting on the physical seizure of the paper rather than the illegal entry. On Lee v. United States, stupra at 753 ; Lopez v. United States, supra (assumption that distinction in On Lee is valid). See also Fraternal Order of Eagles No. 778 v. United States, 57 F.2d 93 (3d Cir. 1932).

49 McDonald v. United States, 335 U.S. 451 (1948) (discussed at note 37 sispra); Taylor v. United States, 286 U.S. 1 (1932). A possible exception to this rule might arise in an emergency. For an acknowledgement of this exception see McDonald v. United States, supra at 454-55; Johnson v. United States, 333 U.S. 10, 14-15 (1948). See also 51 CalfF. L. Rev. 637,641 (1963). 
police officers will not be allowed to use the color of their authority to gain entry. ${ }^{50}$

An eavesdropper may often be out of the range of the fourth amendment although he is clearly trespassing on the defendant's property. A physical intrusion violates the fourth amendment only if it probes into an area that, in the Court's opinion, is so essential to the individual's privacy that it demands constitutional security. The landmark case of Hester v. United States $\mathbf{5 1}$ involved a defendant who, as he was coming out of his father's house with illicit moonshine whiskey, was seen by a revenue agent concealed 50-100 feet from the house but trespassing on the father's property. Justice Holmes responded to the defendant's claim of a fourth amendinent violation as follows: " $[\mathrm{I}] \mathrm{t}$ is enough to say that, apart from the justification, the special protection accorded by the Fourth Amendinent to people in their 'persons, houses, papers, and effects', is not extended to the open fields." 52 The protected area is, for the most part, the defendant's "curtilage": the area where the domestic activities of the family are carried on, and would include all structures or open spaces used for everyday family purposes. ${ }^{53}$ In addition, the Court has extended protection to automobiles, ${ }^{54}$ places of business, ${ }^{\text {t5 }}$ and other dwelling areas. ${ }^{56}$

\section{California Legislation}

Several states have responded to the eavesdropping problem by enacting legislation regulating the use of electronic surveillance devices. ${ }^{57}$ The response is no doubt due largely to the Supreme Court's inability to propose a satisfactory formula which would distinguish those encroachments on privacy which are acceptable by the community's standards from those which violate fundamental rights. California offers three statutes ${ }^{58}$ to meet this need for restriction.

50 Johnson v. United States, supra note 49, at 16-17 (admission gained under color of authority is illegal). See also Gouled v. United States, 251 U.S. 298 (1920), discussed at note 48 sulpra. But cf. York v. Story, 324 F.2d 450 (9th Cir. 1963).

51265 U.S. 57 (1924).

52 Id. at 59.

5: For a more refined definition of curtilage see United States v. Benson, 299 F.2d 45 (6th Cir. 1962) (islands separated from house by stream not withm curtilage); United States v. Potts, 297 F.2d 68 (6th Cir. 1961) (house not used as residence outside curtilage) ; People v. Hodges, 243 F.2d 281 (5th Cir. 1957) (chicken house separated from residence by 150 feet and two fences not within curtilage); Wakkuri v. United States, 67 F.2d 844 (6th Cir. 1933) (bathhouse adjacent to house within curtilage); Temperani v. United States, 299 Fed. 365 (9th Cir. 1924) (garage under a one-story dwelling within curtilage). In United States v. Minker, 312 F.2d 632 (3d Cir. 1962), cert. denied, 372 U.S. 953 (1963), a trash receptable used by three apartments and kept outside the building was held not to be within the curtilage. This case broke new ground by setting up a balancing of factors test dependent upon proximity to the building, use to domestic life of family, and location within an enclosed area. Id. at 634 .

54 Rios v. United States, 364 U.S. 253 (1960) (taxicab) ; Carrol v. United States, 267 U.S. 132 (1924) (private auto).

55 Silverthorne Lumber Co. v. United States, 251 U.S. 385 (1920) (business office); Amos v. United States, 255 U.S. 313 (1921) (store).

50 Lustig v. United States, 338 U.S. 74 (1949) (hotel room). The Court has been more than willing to extend protection in this sort of situation. But see Lanza v. New York, 370 U.S. 139, 143-44 (1962), where the Court was of the opmion that a jail shared none of the attributes of these constitutionally protected areas.

57 See Report of the Joint Legislative Committee on Privacy of Communications and Licensutre of Private Investigators, State of New York, 61-64 (1961) ; DaSH 430-39.

58 Cal. Pen. Code $\$ \$ 653(\mathrm{i}), 653(\mathrm{~h}), 653(\mathrm{j})$, Cal. Stat. ch. $1886 \$ 1$ (1963). For a survey of the actual practices of electromc eavesdropping in Cahfornia see DASH 161-216. 
California Penal Code Section 653(i) was adopted to protect a limited abuse by police officers. The statute prohibits (without consent of all parties) eavesdropping by a law enforcement officer or other public agent on a person in the custody or on the premises of the public agent when the conversation is with his attorney, religious advisor, or licensed physician. ${ }^{50}$

California Penal Code Section $653(\mathrm{~h})$ prohibits the installation or attempted installation of a "dictograph" without the consent of the "owner, lessee, or occupant," in a number of enclosed places, the list of which seems to be all inclusive. A "regular salaried police officer" acting with proper authorization is not restricted by the statute. Briefly, the problems presented by this statute center on what is meant by "dictograph;" 00 why the consent of the "owner, lessee, or occupant" is required when it seems to have been the legislative intent to require only the consent of the person in rightful possession; ${ }^{61}$ and what public officers are "regularly salaried police officers." 62

In 1963 the California legislature added Penal Code Section 653(j), which expressly provides that neither section 653 (i) nor section $653(\mathrm{~h})$ is to be considered repealed. ${ }^{63}$ Section $653(\mathrm{j})$ prohibits electronic recording or amplifying by one "not a party to the communication." Face-to-face recordings when the recording person is a party to the conversation would be permissible under the statute. Thus, the kind of recording in On Lee and Lopez is legal in California. Other electronic recording and anplifying is prohibited "without the consent of any party to a confidential communication." ${ }^{\prime} 4$ The history of the bill indicates that "any party" means that only one party's consent is required. ${ }^{65}$ The statute imposes a criminal penalty for any violation and provides for exclusion of evidence so obtained. The statute applies to "every person or his autliorized agent." Both federal and state government officials are specifically included in the section's definition of "person." The last provision of the statute, ${ }^{86}$ however, com-

59 Cf. People v. Hughes, 203 Cal. App. 2d 598, 21 Cal. Rptr. 668 (1962) (section not applicable to a conversation with wife and daughter). Compare Lanza v. New York, 370 U.S. 139 (1962) (dicta that jail is not a constitutionally protected area).

60 Dictograph, within the meaning of this section, includes only devices used for electrical transmission of sound from the place where it is heard to another place where it is made audible. People v. Albert, 182 Cal. App. 2d 729, 9 Cal. Rptr. 473 (1960) (a minifon is not a dictograph within the mcaning of the section). See also People v. Wootan, 195 Cal. App. 2d 481, 15 Cal. Rptr. 833 (1961) (concealed transmitter not a dictograph within the section); People v. Sica, 112 Cal. App. 2d 574, 247 P.2d 72 (1952) (microphone placed next to phonc not a dictograph within the section); DASH 431; Report of the California Senate Judiciary Committee on the Interception of Messages by the Use of Electronic and Other Devices 17 (1957) [Herinafter cited as 1957 Calif. Hearings].

61 See DasH $431 ; 1957$ Calif. Hearings 17.

62 See DASH 430-31; 1957 Calif. Hearings 17.

63 Cal. Assembey BIII No. 2474 (1963), was introduced on the hecls of Cat. Pen. Code $\S 653(\mathrm{j})$, for the purpose of repealing $\S 653(\mathrm{~h})$ and to add a new section, $\S 653(\mathrm{~h})$. Both bills were introduced by Assemblyman Burton, so perhaps the clarity and scope of $\S 653(\mathrm{j})$ was made to depend largely upon the new and revised $\$ 653(\mathrm{~h})$ that was also proposed.

64 A "confidential communication" is defined as "any communication carried on in such circumstances as may reasonably indicate that the parties to such communication desire it to be confined to such parties ...." CaL. PEN. Code $\$ 653(j)(c)$.

65 Section 653(j)'s original draft, CAL. Assembly BILL No. 2473 (1963), provided for the consent of "ail parties." The change to "any party" must necessarily indicate that one party's consent will suffice.

66 "Nothing in this section shall be construed as prohibiting law enforcement officers from doing that which they are otherwise authorized by law to do." Cal. PEN. ConE $\S 653(\mathrm{j})(\mathrm{h})$. 
pletely excludes law enforcement officers from the restrictions provided. It appears that the bill, as originally introduced, was clearly applicable to law enforcement officers and was then hurriedly changed to exclude them. ${ }^{67}$

The total effect of California's statutory provisions falls short of furnishing adequate protection. Three statutes, which confusingly overlap, are provided where clarity would demand one comprehensive provision. There is a gaping hole where certainly at least some control is needed-restriction of police surveillance. In contrast to the absence of restrictions on police, section $653(\mathrm{j})$ would appear to forbid nearly all private electronic eavesdropping. Although legislation is the only means of controlling eavesdropping by individual citizens (private action not being within the purview of the 14th amendment), it may still be argued that section $653(\mathrm{j})$ unduly restricts the private individual. Electronic surveillance is prohibited on one's own property unless the consent of one of the parties to the conversation is obtained. This broad restriction will prevent certain apparently necessary uses such as monitoring of suspicious employees to detect embezzlement or fraud and would go so far as to prohibit the use of a recorder in conjunction with a burglar alarm system. ${ }^{68}$

It is interesting to note that New York has also devoted considerable attention to legislation in this area and has been similarly unsuccessful. ${ }^{69}$ The fact that the legislatures of the nation's two most populous states have not been able effectively to deal with the problem does not necessarily indicate that legislation is an infeasible means of restricting electronic eavesdropping. A workable legislative solution is certainly possible-yet more is needed in the way of thorough and careful analysis.

\section{III}

\section{LOOKTNG FORWARD}

\section{A. The Fourth Amendment-A Parochial Construction}

Pre-Olmstead cases clearly recognized a right of privacy which was not dependent upon the sort of literal reading which the Olmstead Court gave the fourth amendment. ${ }^{70}$ Olmstead, however, has for 30 years been thought to preclude protection absent a physical invasion. In an attempt to take up this slack, numerous other constitutional bases have been suggested to safeguard the right of privacy. These suggestions have included the Court's supervisory power, ${ }^{71}$ the due

67 See CAL. ASSEMRLY BII 2473 (1963). This bill did not contain the provision excluding law enforcement officers. See note 66 supra.

6s For many examples of the useful service of some similar practices see Lipset, The Wiretapping-Eavesdropping Problem: A Private Investigator's View, $44 \mathrm{MINN}$. L. Rev. 873, 880-\$4 (1960).

CO See DASH 35-51, 411-416; Report of the Joint Legislative Committee on Privacy of Communications and Licensure of Private Investigators, State of New York, 56-57 (1961). But for the recent developments of the law of New York see Report of the Joint Legislative Committee on Privacy of Communications and Licensure of Private Investigators, State of New York (1962). See also Silver, The Wiretapping-Eavesdropping Problem: A Prosecutor's View, 44 MINN. L. REv. 835, 839 (1960).

70 See authorities cited at note 10 supra.

71 This basis refers to the Supreme Court's power to formulate and apply standards of procedure and evidence in federal courts. See, e.g., Mallory v. United States, 354 U.S. 449 (1957); Rea v. United States, 350 U.S. 214 (1956); Upshaw v. United States, 335 U.S. 410 (1948); McNabb v. United States, 318 U.S. 332 (1943). See also McCormick, Evidence 246-51 (1954); Kamisar, The Wiretapping-Eavesdropping Problem: A Professor's View, 44 
process clauses of the fifth and fourteenth amendments, ${ }^{72}$ and the first amendment. ${ }^{73}$ Nevertheless, if the "right to privacy" is to receive recognition from the Supreme Court, by far the most satisfactory basis for recognition is the fourth amendment. ${ }^{74}$. It seems equally clear that the individual's mimimum rights to be protected under that amendment have not been fully spelled out by the Court. Surely a majority of the Court recognizes, as did Justice Douglas in Silverman, ${ }^{75}$ that the requirement of a physical invasion may bear no reasonable relation to the degree of the invasion of privacy.

Perhaps the reluctance of the Court to rid the fourth amendment from the requirement of a physical invasion has been due largely to a fear of banning all electronic surveillance techniques, both good and bad, from police use. The argument made by a minority of the Suprene Court ${ }^{76}$ for bringing electronic eavesdropping within the grasp of the fourth amendment does present an allor-nothing proposition. The basis of this argunient is that the use of any electronic device to overhear a conversation is a "search" within the meaning of the fourth amendment. Since the fourth amendment would normally require a warrant to be issued for this searching procedure 77 "particularly describing" the "things to be seized," the use of any electronic device would depend upon meeting those requirenients. Electronic surveillance would thereby be stopped at the desk of the niagistrate. A search warrant can be issued only for those objects which the

Mins. L. REv. 891, 926-27 (1960) (the author strongly advocates the exercise of the power). See generally Kamisar, Illegal Searches or Seizures and Contemporaneous Incriminating Statements: A Dialogue on a Neglected Area of Criminal Procedure, 1961 U. Itc. L.F. 78.

The supervisory power, however, is restricted to federal courts and, in addition, seems to be limited to a violation of a specific federal law or rule of procedure. See Lopez v. United States, 373 U.S. 427,440 (1963) and On Lee v. United States, 343 U.S. 747, 754 (1952).

72 See, e.g., Irvine v. California, 347 U.S. 128, 142-49 (1954) (Frankfurter, J., dissenting). His argument was based on Rochin v. California, 342 U.S. 165 (1952), in that he thought that the accused was being deprived of a fair trial in the sense in which that idea is incorporated in due process. See also Katzenbach, An Approach to the Problems of Wirelapping, 32 F. R. D. 107, 110 (1963) ; Beaney, The Constitutional Right to Privacy in the Supreme Court, 1962 SUP. CT. REv. 212, 246-49; cf. York v. Story, 324 F.2d 450 (9th Cir. 1963), discussed in note 40 supra. See generally Nutting, The Fifth Amendment and Privacy, 18 U. PIrT. L. REv. 533, 543 (1957).

${ }_{73}$ This theory originates from King, Wire Tapping and Electronic Surveillance: A Neglected Constitutional Consideration, 66 DICK. L. REv. 17, 24-38 (1961). The theory is that the loss of freedoni of expression due to fears of being overheard violates the first annendment. But see Lopez v. United States, 373 U.S. 427, 470 (1963) (Brennan, J., disavowing this position in his dissent).

T4 A good many Supreme Court justices over the years have advocated this position, Sce, e.g., Olmstead v. United States, 277 U.S. 438, 475 (1928) (Brandeis, J., dissenting); Goldman v. United States, 316 U.S. 129, 136 (1942) (Murphy, J., dissenting); On Lee v. United States, 343 U.S. 747, 762 (1952) (Douglas, J., dissenting); Lopez v. United States, 373 U.S. 427, 446 (1963) (Brennan, J., dissenting; Justices Douglas, Goldberg, coneurred in the dissent).

75 "The concept of 'an unauthorized physical penetration into the premises,' on which the present decision rests, seems to me to be beside the point. Was not the wrong in both cases done when the intimacies of the home were tapped, recorded, or revealed? The depth of the penetration of the electronic device-even the degree of its remoteness from the inside of the house-is not the measure of injury." Silverman v. United States, 365 U.S. 505, 513 (1961) (Douglas, J., concurring).

76 See, e.g., Lopez v. United States, 373 U.S. 427, 459 (1963) (Brennan, J., dissenting); Dovglas, THE Right OF THE PEOPIE 149 (1958).

77 See Agnello v. United States, 269 U.S. 20 (1925); cf. Chapman v. United States, 365 U.S. 610 (1961). See also Schwartz, On Current Proposals to Legalize Wire Tapping, 103 U. OF PA. L. Rev. 157, 163-64 (1954); Note, The Sutpreme Courl, 1960 Term, 75 HARv. L. REv. 40, 187 (1961). 
government has a right to seize; ${ }^{78}$ these are the fruits or tools of a crime. The electronic device searches only for evidentiary matter, and this makes it unreasonable per se. ${ }^{79}$ The definiteness requirement would pose an additional problem as electronic surveillance would in the typical case be a "fishing expedition"; the defendant's whole life would be exposed, as well as the lives of others not suspected of any crime but simply within the range of the surveillance. To add to the difficulty, a search warrant requires notice, ${ }^{80}$ while the effectiveness of electronic surveillance depends on a lack of notice. This approach, it can be readily seen, leads to a total ban ${ }^{81}$ on electronic surveillance and for this reason has not been accepted by a majority of the Supreme Court.

\section{B. Lopez v. United States-A New Approach}

The most recent Supreme Court case in this area is Lopez v. United States. ${ }^{82}$ Petitioner was convicted on three counts of attempted bribery of Davis, an Internal Revenue Agent. The convictions were based on the testimony of Davis relating to an October 24, 1961 conversation with petitioner and, in addition, a recording of that conversation obtained by a minifon concealed on Davis. Prior to this conversation Davis was offered, and accepted, 420 dollars from Lopez to forget certain tax delinquencies which Davis had discovered. Three days later Davis returned equipped with the minifon, asked to speak to Lopez in his office, and recorded the three attempted bribes for which Lopez was convicted. One of the two questions ${ }^{83}$ before the Court was whether Davis' testimony and the recording of the October 24th conversation were properly admitted into evidence. In attempting to invoke the fourth amendment, Lopez contended that "by falsification of his mission" Davis had "gained access to petitioner's office by misrepresentation and all evidence obtained in the office ... was illegally 'seized." "84 The Court rejected this claim and pointed out that Davis was there with petitioner's consent and was not guilty of an unlawful invasion of petitioner's office simply because "his apparent willingness to accept a bribe was not real." 85 The testimony of Davis was therefore admissible. With respect to the recording, the traditional approach would be to hold that since Davis had not committed a physical invasion, neither had the minifon; thus Olmstead, Goldman, and On Lee would permit the adnission of the evidence. Another alternative, taken by the dissent, ${ }^{88}$ would be to declare the recording a "search" within the meaning oi the fourth amendment, exclude the evidence as obtained from an unreasonable search and seizure, and thereby overturn Olmstead, Goldman, and On Lee. The

78 See Gouled v. United States, 255 U.S. 298, 309-11 (1921). See also Kamisar, The Wiretapping-Eavesdropping Problein: A Professor's View, 44 MnNo. L. REv. 891, 914-18; Note, The Supreme Court, 1960 Term, supra note 77, at 187.

78 See Schwartz, supra note 77; 1958 Hearings 1486 (testimony of Edward Bennett Wiliams); authorities cited at note 78 supra.

80 See FED. R. CRnor. P. 41(d). State requirements may differ somewhat from federal requirements. To what extent Ker v. California, 374 U.S. 23 (1963), requires compliance with federal standards is still an open question.

81 Accord Lopez v. United States, 373 U.S. 427, 463-66 (1963) (Brennan, J., dissenting); Schwartz, supra note 77 , at 164.

82373 U.S. 427 (1963).

83 The other question before the Court was the defense of entrapment. It is enough to say that under the facts of Lopez the defense is extremely flimsy.

84373 U.S. at 437.

85 Id. at 438 .

86 Id. at 459 (dissenting opinion). See note 77 supra and accompanying text. 
Court used neither theory in disposing of the recording, but rather held that the conduct was "not eavesdropping" 87 in any sense of that word.

In reaching this conclusion the majority did not pay even passing attention to On Lee. Interestingly enough Justices Brennan, Douglas, and Goldberg, dissenting, thought $O n$ Lee to be the only decision of the Supreme Court factually analogous to Lopez and concluded that the majority's failure to consider the case could only be attributed to their lack of confidence in its vitality. ${ }^{88}$ Chief Justice Warren thought $O n$ Lee to be so similar that he wrote a concurring opinion for the apparent purpose of explaining why he was not affirming On Lee by siding with the majority in Lopez. It appears that the Chief Justice had no dispute with the use of the recording device in $O n$ Lee, but objected to the introduction of the recording in lieu of the testimony of the party to whom the disclosures were made (In On Lee Chin Poy did not appear at trial), thus depriving the defendant of a chance to cross-examine his accusor. ${ }^{80}$

Olmstead and Goldman were summarized by the majority as marking an area where the Court had allowed electronic eavesdropping when the devices used permitted government agents to "overhear conversations which would have been beyond the reach of the human ear." ${ }^{\prime 90}$ Lopez was distinguished from Olmstead and Goldman on this basis; the government had not used a device to enable them to hear a conversation they could not otherwise have heard. The Court did not examine Olmstead, Goldman, or Silverman ${ }^{91}$ because Lopez, unhike those cases, had involved no eavesdropping. There had been no physical invasion, as in Silverman, and the government agent was able to hear the conversation without the aid of the device.

It is important to note that the Court's decision to affirm the admittance of the evidence could have been based solely on the absence of a physical invasion. ${ }^{92}$ The motive in isolating the use of the electronic device in Lopez from that in Olmstead, Goldman, and apparently On Lee is not immediately visible. Perhaps

87 Id. at 439.

88 Id. at 447 (dissenting opinion).

89 An unwillingness to trust completely the recording party, coupled with a desire to give the defendant every procedural advantage feasible seems to lead Chief Justice Warren to the conclusion that the Court's supervisory power should be invoked to exclude the recording when, as in $O n L e e$, the recording party is not subjected to cross-examination. The absence of Chin Poy from trial in On Lee deprived On Lee of two valuable weapons: (1) an important means of impeaching the credibility of the informer, Chin Poy, and (2) an opportunity to disclose any psychological pressures or unsavory traps which might have called into play the Court's supervisory power. Id. at $443-46$ (concurring opinion). See note 72 supra.

The Chief Justice also pointed out that smce Davis was only protecting his reputation as a public agent against possible attacks or denials by the accused, there was a compelling reason to allow the recording. Id. at 442 (concurring opinion).

$80 \mathrm{Id}$. at 438.

91 Id. at 439.

92 Olmstead v. United States, 277 U.S. 438 (1928); Goldman v. United States, 316 U.S. 129 (1942); or On Lee v. Umited States, 343 U.S. 747 (1952), would have supported this. The Court, lowever, placed a good deal of reliance on the principle of Rathbun v. United States, 355 U.S. 107 (1957). In that case the testimony of a policeman was admitted into evidence although lie had overheard the conversation in question on an extension telephone with the consent of one of the parties. This is, of course, a $\S 605$ question and one of statutory construction. The principle involved here, however, does seen analogous to that of Lopez. Justice Brennan, dissenting, attempted to distinguisl the cases not only on the ground that Rathbun involved a statutory question but also on the ground that there is a significantly greater risk of being overheard when speaking into a telephone. 373 U.S. at 452,453 n.2 (dissenting opimion). 
one consideration was the Court's hesitancy to recognize the continued validity of Olmstead and thereby make the case more difficult to overturn at the proper time. One could view the decision as setting aside a part of the electronic surveillance techniques to remove them from the anticipated grasp of the fourth amendment. The majority in Lopez may well have recognized that fourth amendment protection from the electronic device absent a physical mvasion is inevitable, but desired to insure the future of electronic recording, as distinguished from electronic eavesdropping. Thus, if Olmstead tumbles, Lopez need not accompany it; that is, if electronic eavesdropping is declared to be a search withm the meaning of the fourth amendment, the Lopez type of recording, which is not eavesdropping, will still be admissible. With certain useful electronic surveillance techniques safely outside the grasp of the fourth amendment, the Court can eliminate a significant consideration for not overruling Olmsteadperhaps the one that has kept it alive.

In making this distinction the Court in Lopez seems to recognize that it is not the electronic device that is evil but rather the invasion of privacy it can create, and further, that all uses of such devices do not necessarily invade privacy. It is not at all clear, however, what the Court means to define as "not eavesdropping." In Lopez the Court could not see any argument that would justify "excluding an accurate version of a conversation that the agent could testify to from memory." ${ }^{83}$ This qualification would include any recording of a conversation that the agent did in fact hear and could testify to. The opinion of Chief Justice Warren expressed a similar view in that he felt that a public agent should be allowed to support his own testimony with a recording as a means of protecting his credibility. ${ }^{94}$ The majority in Lopez, aware of the advantage of providing an accurate version of a conversation at trial, was of the opinion that an electronic reproduction is within the risk taken by one who makes a damaging disclosure. ${ }^{95}$ Justice Brennan, dissenting, did not agree; this sort of risk, he said, is "of a different order." 96 With the Lopez decision established, it seems likely that the sort of disclosure made in On Lee (speaking to an old friend as compared to bribing an Internal Revenue Agent), would today receive similar treatment. ${ }^{97}$

The Court's definition of "not eavesdropping" may possibly extend to conversations that were not in fact lieard by the agent, but could have been heard without committing a physical invasion. The Court speaks of "eavesdropping" as recording conversations "which would have been beyond the reach of the human ear," and later, as those which the government agent "could not

93 Id. at 439.

94 Id. at 442 (concurring opinion). See note 89 supra.

85373 U.S. at 439.

08 Id. at 450 (dissenting opinion) (mechanical auditors not within this risk). Compare Lopez, id. at 450-51 (Brennan, J., dissenting), 465-66, with Warren and Brandeis, The Right to Privacy, 4 HARv. L. Rev. 193, 198 (1890).

87 It appears that the government in Loper had little faith in the validity of $O n$ Lee as they went to great lengths to distinguish it. The government contended that in On Lee the defendant had not intended to commumicate his words to another person and they had in fact reached another person via the hidden transmitter. This analysis was to be compared to Lopez where the agent simply recorded his own impressions. Justice Brennan, however, did not allow such a tenuous distinction to slip by unnoticed. He contended that a minifon is received as independent evidence in the same manner as a third party actually testifying and therefore the invasion is exactly the same in either case. Lopez v. Unitd States, 373 U.S. 427, 447-48 (1963) (Brennan, J., dissenting).

88 Id. at 438. 
otherwise have heard." ${ }^{89}$ This language could possibly be read as including the recording of a conversation that if heard by the agent without an electronic aid would not have resulted in a physical invasion. Hence, the Lopez opinion raises the question of whether constitutional protection will be extended to include: (1) recordings of conversations which take place on protected premises but which could have been heard by the agent from an unprotected area, and (2) recordings of conversations that take place on public, ${ }^{100}$ rather than protected premises.

\section{Physical Invasion Revisited-Lopez and Beyond}

It is undoubtedly true that the sort of search the framers of the fourth amendment intended to protect against was a physical one. It is not surprising, therefore, that the test which has developed for the application of this amendment has been phrased in terms of a physical invasion. It should be equally apparent, however, that the physical invasion, while still a threat to the integrity of the individual, has been joined by a new threat-electronic invasion. Thus the old maxims do not, by themselves, provide adequate protection. On the other hand, those who ${ }^{101}$ advocate a total departure from the physical invasion theory go too far, because they fail to recognize that the theory produces a proper result in many types of cases. Hence, what is needed is not a revolution but merely a reform which will bring the physical invasion approach up to date.

In bight of Lopez, the panoply of electronic surveillance equipment can be divided into two categories: (1) devices that serve only to record accurately conversations, images, or other data which are perceptible to the human senses, and (2) devices that secure conversations or happenings which are not otherwise perceptible to the human senses. The Court's opinion in Lopez makes it quite clear that law enforcement officers do not violate the Constitution by recording information they themselves lawfully heard, without committing a pliysical invasion. But the Court leaves entirely at large the question of whether there is an unconstitutional search when a government agent, by using a supersensitive device, audits a conversation he could not otherwise have heard. If the Court finds this search unconstitutional, then the dogma of Olmstead will give way to a theory that would provide essentially the same protection as did the physical invasion concept before the advent of electronic surveillance. This question becomes more crucial, of course, as the time approaches when walls and distances will provide no privacy from the omnipotent eyes and ears of law enforcement officers. Justice Brandeis foresaw 35 years ago that such a day would come. ${ }^{102}$ There might have been grounds for doubting the soundness of this prediction when made, but who can question it today? Soon this fact must be accepted by the Supreme Court, and when, at last, the Court recognizes that physical barriers and physical space are no longer valid protectors of privacy, then also must the inadequacy of the physical invasion test be conceded. In its place must arise a barrier against both physical invasions and those electronic invasions which produce essentially the same result.

William J. Hoese

98 Id. at 439.

100 But see the result of such a use in Lanza v. New York, 370 U.S. 139 (1962) (governinent eavesdropping in a jail).

101 See note 75 supra.

102 See Olmstead v. United States, 277 U.S. 438, 474 (1928) (Brandeis, J., dissenting). 